\title{
Disposal of waste from cementing operation from offshore oil and gas wells building
}

\author{
Letícia Ferraço de Campos ${ }^{1}$, Pedro Mello Paiva ${ }^{1}$, Pedro Paulo Gomes Watts Rodrigues ${ }^{2}$, \\ Maria Inês Paes Ferreira ${ }^{1}$, Jader Lugon Junior ${ }^{1}$ \\ ${ }^{1}$ Instituto Federal Fluminense \\ leticiaferraco@hotmail.com; pedromellopaiva@gmail.com; ines_paes@yahoo.com.br; jlugonjr@gmail.com \\ ${ }^{2}$ Universidade do Estado do Rio de Janeiro \\ pedropaulowatts@gmail.com
}

\begin{abstract}
This paper presents computer modeling applied to the disposal simulation residual volume from offshore cementing unit, where the cement paste used by cementing operations of oil and gas wells. The software used was MOHID WATER with a lagrangian approach where the solid part of the residue was represented by conservative particles. It is able to assess the behavior of the solid part of the residue in the water column and its accommodation on the seabed. Future works using the Life Cycle Impact Assessment (LCIA) standard methods are considered to understand the results and the possible resulting harm to marine organisms.
\end{abstract}

Keywords: MOHID WATER; Environment impacts; Life Cycle Assessment 


\section{Introduction}

Oil activity is carried out at increasingly restrictive environmental regulation being ceaseless studies and investments in search of sustainability in this field (DIAS, 2005). Studies are been made to understand the potential harm to marine environment caused by Offshore Oil and Gas operations and to learn important lessons from catastrophic occurrences (BEYER et al., 2016; WHITE AND BERRY, 2014).

Drilling operations and well cementing usually generate a large amount of waste and residual waters, so the environmental impact is inevitable. On Table 1 is shown the waste that can be generated at each step at the construction of oil and gas wells (IBAMA, 2014).

Table 1 - Waste from drilling and cementing operations

\begin{tabular}{c|c}
\hline Operation & Waste \\
\hline \multirow{4}{*}{ Drilling } & Drilling Fluids \\
\cline { 2 - 2 } & Additional fluids \\
\cline { 2 - 2 } Cementing & Drill cuttings \\
\cline { 2 - 2 } & Wash water \\
\cline { 2 - 2 } & Mixing water \\
\cline { 2 - 2 } & Additional fluids \\
\hline \multirow{4}{*}{ Source: Adapted from (IBAMA, 2014) }
\end{tabular}

There is a great research effort to measure the impact caused by particulate emissions on marine ecosystems using Life Cycle Impact Assessment (LCIA) standard methods (MENDES et al. 2016; ROSENBAUM et al., 2008; VELTMAN et al., 2011; WOODS et al., 2016). Although different physical pressures of particles characterization factors were developed, such as turbidity increase and burial of benthic communities due to particle deposition on the seafloor, only the latter will be considered in this work.

Along the drilling operations, the most part of waste cuttings is associated with water-based drilling fluids and non-aqueous based drilling, both natural byproducts of the geological formation. In the cementing operations, the washing waters from cement cleaning units is generated in large volumes and with a relative high frequency. Table 2 shows the average volume of drill gravels and washing waters that can be generated during construction of a typical well 5 stages-well.

Table 2 - Average volume of gravels and washing waters that can be generated during the construction of a typical 5 stages-well

\begin{tabular}{c|c}
\hline Waste & Volume generated* \\
\hline Drill gravels & $239 \mathrm{~m}^{3}$ \\
\hline Wash water & $18 \mathrm{~m}^{3}$ \\
\hline $\begin{array}{c}\text { *Generation average during construction of a well depth } \\
\text { of } 5 \text { phases to around } 3000 \mathrm{~m} .\end{array}$ \\
\hline \multicolumn{2}{c}{ Source: The author (2016) }
\end{tabular}

The offshore disposition of washing waters, as well as other kinds of waste generated during cementing operations, is prohibited by the Brazilian Environmental Agency (IBAMA). So, all waste from cementing operations are temporarily stored in tanks on drilling rigs, called cementing boxes, which need to be transported (both by sea and land) 
to the final disposition site. Dealing specifically with the washing waters residues issue, which consists basically of $1 / 20$ parts of cement to fresh water, the solid phase is sent to sanitary landfills and the liquid one goes to a plant of industrial effluents treatment.

The increase of processing power of computers associated with their popularization, enable the construction and solution of mathematical models with increasing sophistication, making possible the simulation of a variety of complex processes and phenomena. For example, nowadays is possible to solve mathematical equations that represent the physical phenomena related to the transport of toxic substances in marine waters, an important tool that can be adopted in the assessment of this environmental problem (DIAS, 2005; LEITÃO, 1996).

The marine environment is subjected to physical, biological, chemical and geological processes. So, from the modeling perspective the choice of a particular approach depends on the specific phenomenon that the model itself is intended to simulate. The motivation of this work is to simulate by means of a computer model the behavior of washing waters residues in the open sea environment, considering a hypothetical disposal of them from a cementing unit. Here only physical processes are considered, addressing the hydrodynamics of the chosen region and simulating the behavior of the solid part of the waste in the water column. The adopted model was built in the MOHID software.

MOHID is a computer modeling system developed by the Center for Science and Technology of the Environment and the Sea (MARETEC) at Instituto Superior Técnico (IST), which belongs to the Technical University of Lisbon (UTL) in Portugal (ASCIONE KENOV et al., 2012). It consists of different modules that can work together to simulate the dynamics of water bodies, while MOHID WATER is a three dimensional numerical program so simulate surface water, MOHID LAND is a watershed model to simulate hydrographic basin and aquifers.

For example, MOHID Land was used to simulate the dynamics of water bodies, flow of porous media, infiltration and integrated river basin at Trancão in Portugal (TRANCOSO et al., 2009). MOHID WATER development started in 1985 and over the past few years MOHID System has been used to simulate a variety of physical, chemical and ecological processes at different scales in rivers, estuarine and marine systems, being subjected to continuous improvement and updating due to its application in many research and engineering projects (ACTION MODULERS, 2016; COSTA, 2014; MARETEC, 2016).

As examples of the application of MOHID WATER in open ocean modeling, studies have been done in the North East Atlantic region, including the coastal current of Portugal (COELHO et al., 2002), current behavior along the continental shelf boundary in European Atlantic and the internal generation of tidal waves (NEVES et al., 1998). Oil spills were studied with a 3D grid in in the Caribbean Coast (Colombia) to simulate an offshore blowout (LEITÃO et al., 2013). Recently in Brazil, Franz et al. (2016) used a downscaling methodology to study the south-eastern Brazilian shelf (regional model) and Paranaguá estuarine system (local model).

MOHID WATER is programmed in ANSI Fortran 95 and its system consists of more than 40 modules, which add up to more than 150,000 programming lines, with ability to simulate hydrodynamics, the dispersion phenomena (Lagrangian and Eulerian approach), the water quality and sediment transport (cohesive and non-cohesive) addition of a system module geographic information (SIG), which enables the creation of computational mesh in which simulations are applied. Each module is responsible for managing an information type, it may be understood as a specific model (JULIANO et al., 2012; MIRANDA et al., 2000; PESSANHA et al., 2011). The main MOHID WATER modules are listed in Table 3. 
Table 3 - Main modules MOHID WATER

\begin{tabular}{|c|c|}
\hline Module & Description \\
\hline Model & $\begin{array}{l}\text { Responsible to menage the information flux between the hydrodynamic modul and both transport } \\
\text { modules, as well as the comunication betweeen other submodels }\end{array}$ \\
\hline Hydrodynamic & $\begin{array}{l}\text { Tridimensional baroclinic model with free surface. Calculates the surface level, the velocities and } \\
\text { water flux. }\end{array}$ \\
\hline Water Properties & $\begin{array}{l}\text { Transport model tith eulerin approach, being capable to simulate the evolution of ater properties, such } \\
\text { as temperature, salinity, disolved oxygen etc. }\end{array}$ \\
\hline Lagrangian & Capable to simulate the evolution of the same properties, using a lagragian approach. \\
\hline Water Quality & $\begin{array}{l}\text { Water quality adimensional model that is capable to simulate the cicle of oxygen, nitrogen and } \\
\text { phosfor species. It is acoplated with the transport model, both lagragian and eularian approaches. }\end{array}$ \\
\hline Oil Dispersion & $\begin{array}{l}\text { Oil dispersion model that simulates the oil dispersion caused by concentration gradient and internal } \\
\text { reactions, such as evoporation, emulsification, dispersion, sissolution and dedimentation. }\end{array}$ \\
\hline Turbulence & Turbulence unidimensional model. \\
\hline Geometry & Responsible to save and manage the finite volume information. \\
\hline Surface & Module responsible to manage the contour conditions at the top of the water column. \\
\hline Bottom & Responsible to deal with the contour conditions at the bottom of the water column \\
\hline Open Boudary & Module responsible to save and manage the contour conditions at marine frontier. \\
\hline Discharges & Responsible to deal with the rivers and anthropogenic discharges. \\
\hline Hydrodynamic File & Auxiliary module that is used to save the hydrodynamic solution to a external file.;. \\
\hline
\end{tabular}

Source: Adapted from (MARETEC, 2016).

The hydrodynamic module is a three-dimensional model that solves the Navier-Stokes equations, considering the Boussinesq approache, where it is assumed that all fluid properties are constant except for the density of the weight force term, which varies linearly with temperature. The equations are solved numerically by the Finite Volume Method with a generic vertical discretization which allows simultaneous execution of various types of vertical coordinates (COELHO et al., 2002; FRANZ et al., 2016).

According to Mohid developers (ACTION MODULERS, 2016; MARETEC, 2016; MIRANDA et al., 2000), at first the Lagrangian transport module MOHID WATER was designed be coupled to a two-dimensional hydrodynamic model, solving the primitive equations for shallow waters, making use of the hydrostatic approximation, in a way that it could only simulate the trajectory of drifting buoys. Latter, in a second phase, it was amended to simulate more complex mechanisms (wastewater effluent, specific emissions sediments, emissions of large masses of passive floating pollutants) and water quality studies (determination of residence times of water bodies in specific areas of the domain). Then finally, in a third stage, the coordinate system has been generalized so that it was possible to couple the particle models to 2D and 3D hydrodynamic models. Briefly, the calculation scheme can be divided into three major steps: generation, transport and disposal of the particles (LEITÃO et al., 2013). 


\section{Methodology}

The release of the residue in a marine environment is a problem of multiphase flow in which the continuous phase is constituted by seawater (environment) and the dispersed phase by cement paste. In this work a model was implemented in MOHID WATER through hydrodynamic modules, adopting a lagrangian approach. It is important to note that here the solid phase was treated as a conservative substance, being not subjected to any biogeochemical process.

According to (LEITÃO et al., 2013), the lagrangian approach consists to associate mass to particles emitted at specific points of the domain. The trajectory of each particle is calculated based on a velocity field provided by the coupled hydrodynamic model, and the field concentrations is a function of the particle density in each grid cell. The advective term present in the Navier-Stokes equations is solved indirectly through the trajectory produced by nonturbulent velocity field. The particle location for each instant of time is given by Equation 1:

$$
\frac{d x_{i}}{d t}=U_{i}\left(x_{i}, t\right)
$$

where:

$$
\begin{array}{ll}
x_{i}=x(x, y, z, t) & \text { - particle location at time } \mathrm{t} \\
U_{i}\left(x_{i}, t\right) & \text { - particle velocity. }
\end{array}
$$

Equation 1 is solved by applying a simple explicit method shown by Equations 2 and 3, with enough accuracy to obtain good results for most natural flows (MARETEC, 2016).

$x_{i}^{t+\Delta t}=x_{i}^{t}+\Delta t . U_{i}^{\prime}$

$U=\frac{U_{x} d x_{2}+U_{x+d x} d x_{1}}{d x_{1}+d x_{2}}$

Figure 1 illustrates the $U_{x}$ e $U_{x+d x}$ speeds that are calculated using a simple interpolation, based on the velocity field calculated by coupled hydrodynamic model.

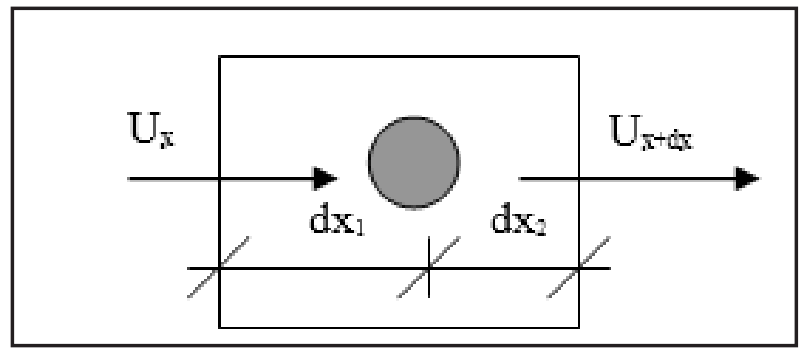

Figure 1 - Calculating the average velocity of the particles

Source: Adaptated from (LEITÃO, 1996)

According to Costa (2003) the particles have six main characteristics: spatial coordinates (x, y, z), a horizontal/vertical random speed, a period of time, during which the particle retains the random velocity, sedimentation 
velocity, mass and volume. For each one of these properties an equation of evolution has to be resolved. Usually the average speed is the main drive for the movement of the particles.

The emission of particles can be done in several ways, spatially and temporally speaking. The spatial emission can be performed by one or multiple sources when each source may correspond to a specific point or to an area defined by a polygon. These particles have the same list of properties and parameters to characterize their random route. The temporal emission of particles can be an instantaneous type or a continuous one (JULIANO et al., 2012; MARETEC, 2016).

According to Leitão (1996), when studying sediments, it is necessary to consider that they have a wide range of dimensions, classified as sand, silt and clay. Another classification criteria is defined by means of activity, i.e., the propensity that a particle has to establish connections with other surrounding particles, in a way that these attractive forces between particles can be sometimes higher than gravitational forces.

In order to be able to simulate the sedimentation process, each particle was associated to a sedimentation velocity, calculated for each particle diameter, $d$, using equation 4 , which calculates the sedimentation rate, $w_{s}$, considering non-spherical particles (MARETEC, 2016; RIJN, 1989).

$w_{s}=\frac{10 v}{d}\left[\left(1+\frac{0.01\left(d_{s}-1\right) \mathrm{gd}^{3}}{v^{2}}\right)^{0.5}-1\right] 100<d<1000 \mu \mathrm{m}$

where:

$$
\begin{aligned}
& d \text { - sediment particle diameter; } \\
& d_{s} \text { - sediment density; } \\
& v \text { - continuous phase kinematic viscosity; } \\
& \mathrm{g}=9.80 \mathrm{~m} / \mathrm{s}^{2}
\end{aligned}
$$

\section{Results and discussion}

Here the simulation of a given disposal of washing waters considered a typical well located at Campos basin, with UTM coordinates of N 116026 and 505437 (SIRGAS, central meridian 33).

The simulations represented a discharge during the first 3 days of March 2013. In this modeling, was neglected a volume of $3.6 \mathrm{~m}^{3}$ of washing water, which correspond to the average volume that is generated during a cementing operation of a well through a pipe with 10 inches of diameter This pipe is placed at depth of 20 meters and has a flow rate of $31.8 \mathrm{~m}^{3} / \mathrm{h}$.

The assumptions and constraints assumed in this work to determine the trajectory of the cement slurry particles in the disposal of waste in question are: (a) cement particles agglomerate has an average diameter of $220 \mu \mathrm{m}$, with a $1.589 \mathrm{~g} / \mathrm{cm}^{3}$ density, resulting in a sedimentation rate of $1.23 \times 10^{-2} \mathrm{~m} / \mathrm{s}$ (result obtained by the equation 3); (b) particles are considered to be inert; (c) the particles are considered not cohesive; (d) the emission of particles is punctual (e); molecular diffusion is negligible compared to the turbulent diffusion. One notes that all lagrangian approach used in this work adopted the hydrodynamic solution developed by (FRANZ et al., 2016).

The area considered in this work is shown in Figure 2, where 42 cartesian layers were superimposed 7 sigma layers. The digital terrain was discretized by a domain mesh with $3 \mathrm{~km}$ x $3 \mathrm{~km}$ cells. 


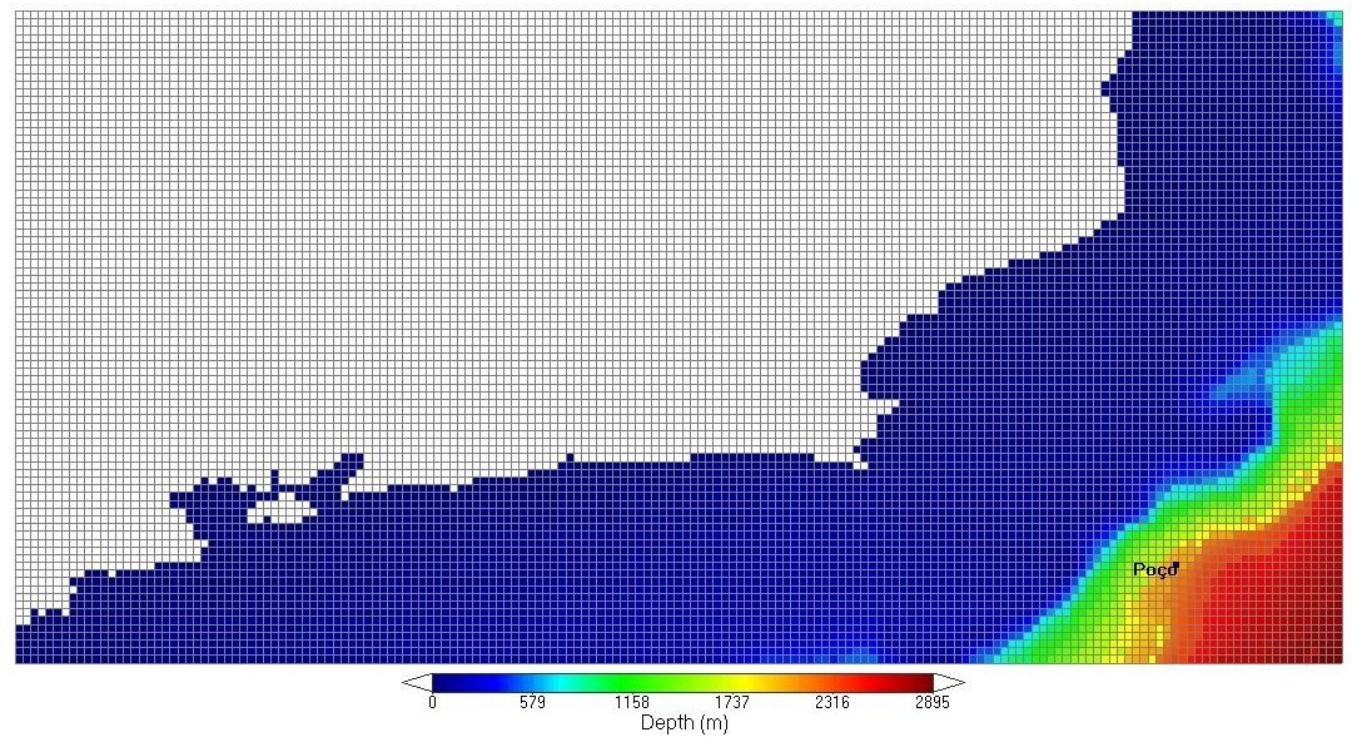

Figure 2 - Digital terrain bathymetry study area, via GIS MOHID interface

Source: The author (2016)

The results calculated by the model are presented in Figures 3 to 5, where one can observe the trajectories of the particles at different times during the three days simulation. Figures 3 and 4 present the results evolution at different times generated at different intervals. It is possible to observe that the plume occupies a quite small portion of domain area. On the other hand, Figure 4 shows the particles distribution on the ocean floor resulting from of the turbulent diffusion at the end of the study period.

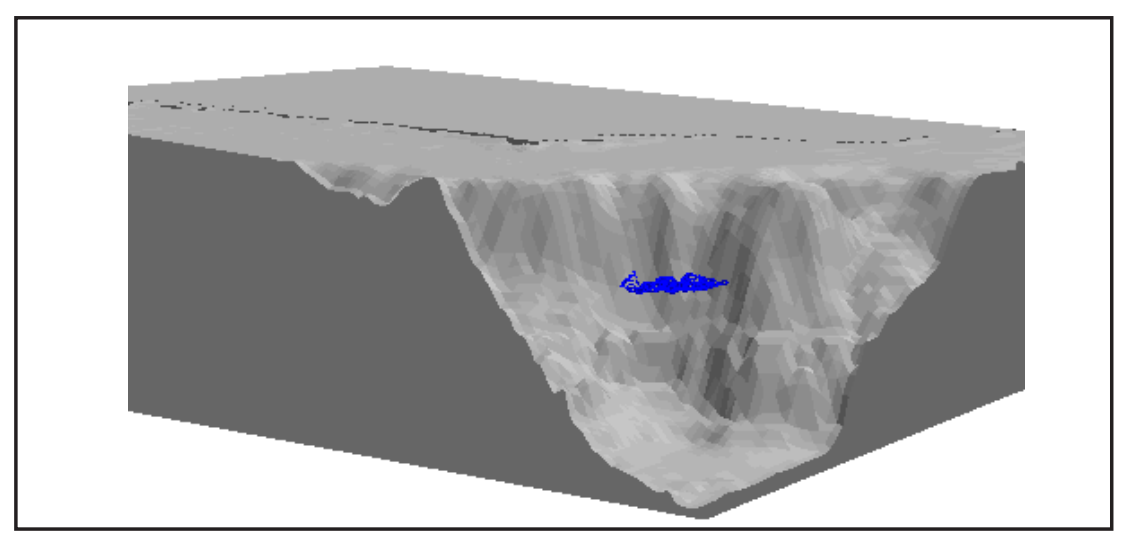

Figure 3 - Trajectory of particles after one day from the start of disposal

Source: The author (2016) 


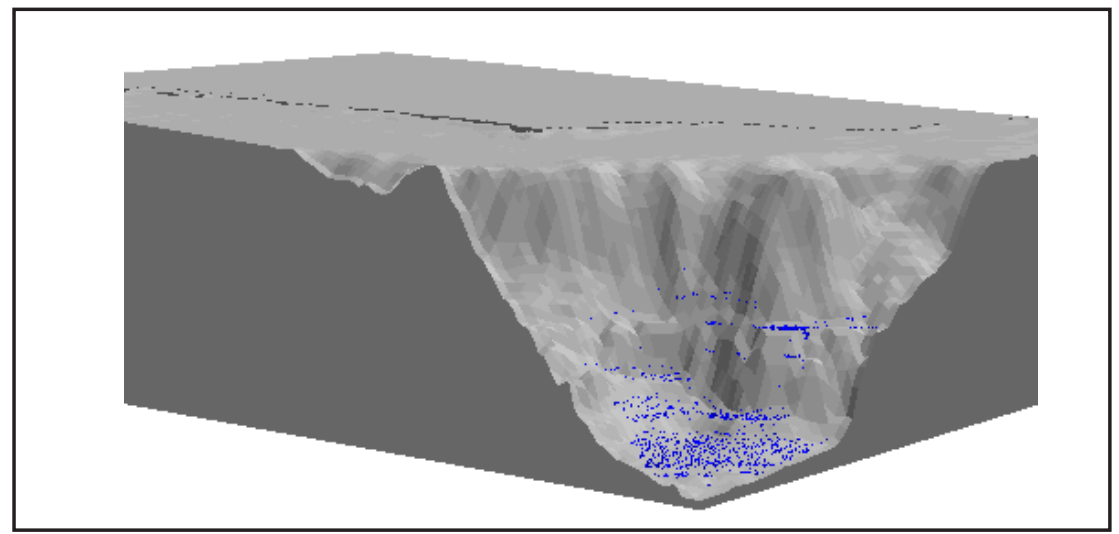

Figure 4 - Accommodation of the particles at the seabed of the study area (three days).

Source: The author (2016)

Figure 5 shows the top view area in the model and the waste particles final resting positions simulated at the end of the run.

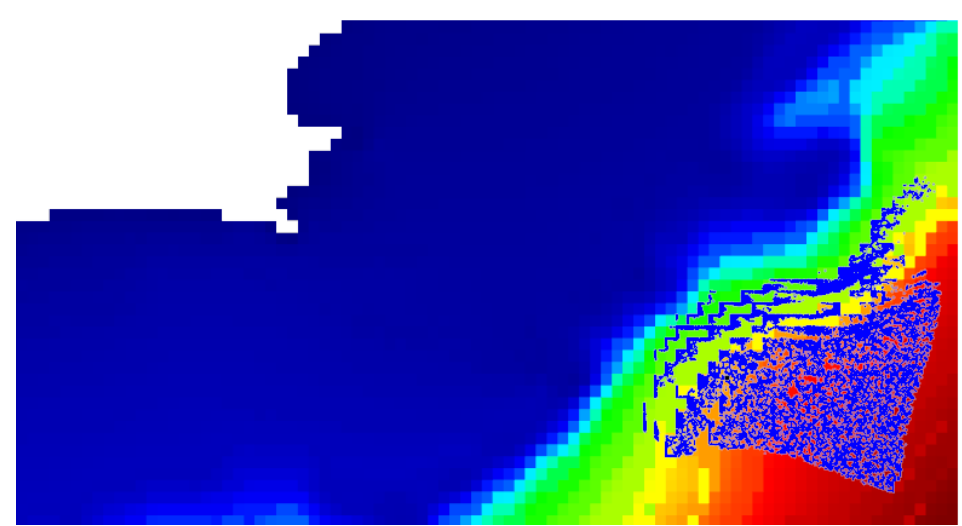

Figure 5 - Top view of the accumulation of particles on the seabed

Source: The author (2016)

The area occupied by the particles estimated by MOHID is around $3627 \mathrm{~km}^{2}$. Considering a washing water density of $1.04 \mathrm{~kg} / \mathrm{L}$ and a released volume of $3600 \mathrm{~L}$, a total of $3744 \mathrm{~kg}$ of residue was discharged, $187 \mathrm{~kg}$ of that as solid phase, resulting to an average of $0.05 \mathrm{mg} / \mathrm{m}^{2}$ for the estimated area. Since a single well building would need 6 sequential discharges and the typical Oil and Gas exploration field at Campos Basin offshore Brazilian coast summing up 100 wells on a $1 \mathrm{~km}^{2}$ area, so the deposition impact can be estimated as an average deposition of $30 \mathrm{mg} / \mathrm{m}^{2}$.

When more precaution is necessary, the maximum deposition at a single simulated cell to estimate the deposition can be used instead of the average, under this assumption that value would be raised to $472 \mathrm{mg} / \mathrm{m}^{2}$. Considering the particle specific mass of $1589 \mathrm{~kg} / \mathrm{m}^{3}$, it is possible to estimate an average sediment layer of $0.3 \mu \mathrm{m}$ caused by the 100 wells building operations, that is, caused by cement washing water disposal at the ocean. With that small amount, the physical burial of benthic communities due to particle deposition on the sea seems to be not relevant. 


\section{Conclusion}

The use of Lagrangian module of MOHID WATER coupled to the hydrodynamic solutions developed by Franz et al. (2016), allowed to visualize a given disposal scenario of washing water residue from cementing operations of oil and gas wells. The simulation indicates that an infinitesimal thickness of particles should be spread over a relatively large area of the seabed at the end of the simulated scenario.

Future works using techniques to evaluate the LCIA Life Cycle Impact Assesment presented by Veltman et al. (2011) can be used considering that particle deposition as the marginal increase in total stressor mass with the knowledge of the marginal increase in effects in a certain impact category (e.g., aquatic toxicity) and the stressor specific bioavailability factor to assess the environmental impact.

This study demonstrated that the computational models can be useful tools in the understanding and assessment of environmental impacts from the disposal of washing water residue. The strategy adopted here can be expanded and optimized considering different refinement assumptions and restrictions assumed during the development of the model. However, further work on waste disposal from cementing offshore oil and gas operations are to be considered: the water column acute and chronic toxic effects on different species, besides the sediments deposit layer, the initial benthic response and benthic recovery rate (VELTMAN et al., 2011). Synergistic impacts of other offshore waste disposal in the ocean, interactions among benthic and higher trophic levels organisms, and exposition effects to human health bring additional complexity, requiring other modeling techniques and primary data gathering methods.

\section{References}

ACTION MODULERS. Mohid Studio. [Internet]. 2016 Jun 10; Available from: http://actionmodulers.pt/products/mstudio/products-mohidstudio2015.shtml

ASCIONE KENOV I, GARCIA AC., NEVES, R. Residence time of water in the Mondego estuary (Portugal). Estuar. Coast. Shelf Sci. 2012;106, 13-22. doi:10.1016/j.ecss.2012.04.008

BEYER J, TRANNUM HC, BAKKE T, HODSON PV, COLLIER TK. Environmental effects of the Deepwater Horizon oil spill: A review. Mar. Pollut. Bull. 2016;110, 28-51. doi:10.1016/j.marpolbul.2016.06.027

COELHO H, NEVES RJ, WHITE M, LEITÃO P, SANTOS A. A model for ocean circulation on the Iberian coast. J. Mar. Syst. 2002;32, 153-179. doi:10.1016/S0924-7963(02)00032-5

COSTA JZG. Influência de uma piscicultura de gaiolas na qualidade da água da zona envolvente [dissertation]. Algarve, Portugal: Universidade de Algarve; 2003.

COSTA VTR. Uso de Modelo Matemático para Avaliação Ambiental sobre Implantação de PCH no rio Itabapoana [dissertation]. Campos dos Goytacazes, Brasil: Instituto Federal Fluminense/IFFluminense; 2014.

DIAS GJ. Modelagem Tridimensional do Lançamento de Rejeitos das Atividades de Exploração e Produção de Petróleo em Águas Profundas [dissertation]. Rio de Janeiro, Brasil: Universidade Federal do Rio de Janeiro/UFRJ - COPPE; 2005 .

FRANZ GAS, LEITÃO P, SANTOS ADOS, JULIANO M, NEVES R. From regional to local scale modelling on the south-eastern Brazilian shelf: case study of Paranaguá estuarine system. Braz. J. Oceanogr. 2016;64, $277-294$. doi:10.1590/S1679-875920161195806403

INSTITUTO BRASILEIRO DO MEIO AMBIENTE E DOS RECURSOS NATURAIS RENOVÁVEIS. Fluidos de Perfuração e Complementares. Rio de Janeiro (Brasil): IBAMA; 2014. 
JULIANO MMF, NEVES R, RODRIGUES PPGW, LUGON JUNIOR J, FERNANDES R. Use of the MOHID Platform for computational simulation of oil ocean drift in the Campos basin - RJ. Bol. Obs. Ambient. Alberto Ribeiro Lamego. 2012;6, 161-172. doi:10.5935/2177-4560.20120010

LEITÃO PC. Modelo de Dispersão Langrangeano Tridimensional [dissertation]. Lisbon, Portugal: Universidade Técnica de Lisboa - Instituto Superior Técnico/IST; 1996.

LEITÃO PC, MALHADAS MS, RIBEIRO J, LEITÃO JC, PIERINI J, OTERO L. An Overview for simulating the blowout of oil spills with a Three-Dimensional model approach (Caribbean Coast, Colombia). In: Ocean Modelling for Coastal Management - Case Studies with MOHID. Lisbon: 1. IST Press; 2013.

MARETEC. MARETEC Home [Internet]. 2016 Out 24; Available from: http://www.maretec.org/en/

MIRANDA R, BRAUNSCHWEIG F, LEITÃO P, NEVES R, MARTINS F, SANTOS A. MOHID 2000 - A coastal integrated object oriented model. Hydraul. Eng. Softw. VIII, WIT Transactions on Ecology and the Environment. 2000;40, 9. doi:10.2495/HY000371

MENDES NC, BUENO C, OMETTO AR. Life Cycle Impact Assessment: review of key methods, Production. 2016;26, 1. doi: 10.1590/0103-6513.153213

NEVES RJJ, COELHO HS, LEITÃO PC, MARTINS H, SANTOS A. A Numerical Investigation Of The Slope Current Along The Western European Margin. Comput. Methods Water Resour. XII Vol 2, WIT Transactions on Ecology and the Environment. 1998;24, 8. doi:10.2495/CMWR980462

PESSANHA CMD, LUGON JUNIOR J, FERREIRA MIP, SOUZA PRN, HORA HMC. The use of computational modeling applied to health and environmental management: a proposal to adapt the MOHID Water platform for lentic bodies applied to Imboacica Lagoon, Macaé, RJ, Brazil. Bol. Obs. Ambient. Alberto Ribeiro Lamego. 2011;5, 45-70. doi:10.5935/2177-4560.20110015

RIJN LCV. Handbook Sediment Transport by Currents and Waves. Delft Hydraulics Laboratory; 1989.

ROSENBAUM RK, BACHMANN TM, GOLD LS, HUIJBREGTS MAJ, JOLLIET O, JURASKE R, KOEHLER A, et al. USEtox - the UNEP-SETAC toxicity model: recommended characterization factors for human toxicity and freshwater ecotoxicity in life cycle impact assessment. Int J Life Cycle Assess. 2008;13, 532-546. doi: $10.1007 / \mathrm{s} 11367-008-0038-4$

TRANCOSO AR, BRAUNSCHWEIG F, CHAMBEL LEITÃO P, OBERMANN M, NEVES R. An advanced modelling tool for simulating complex river systems. Sci. Total Environ. 2009;407, 3004-3016. doi:10.1016/j.scitotenv.2009.01.015

VELTMAN K, HUIJBREGTS MA, RYE H, HERTWICH EG. Including impacts of particulate emissions on marine ecosystems in life cycle assessment: The case of offshore oil and gas production. Integr. Environ. Assess. Manag. 2011;7, 678-686. doi:10.1002/ieam.246

WHITE J, BERRY G. Emergency Response Planning for Subsea Hydrocarbon Release using Advanced Engineering Analysis. Society of Petroleum Engineers. 2014. doi:10.2118/172123-MS

WOODS JS, VELTMAN K, HUIJBREGTS MAJ, VERONES F, HERTWICH EG. Towards a meaningful assessment of marine ecological impacts in life cycle assessment (LCA). Environ. Int. 2016;89-90, 48-61. doi:10.1016/j.envint.2015.12.033 